\title{
AN INTEGRATED STUDY OF COFFEE AND CACAO PLANTATION MANAGEMENT IN SUPPORTING TOURISM-BASED AGRIBUSINESS IN EAST JAVA, INDONESIA
}

\author{
Arig Dewi Mahari SOETRIONO ${ }^{1 *}$ \\ Sri Tjondro WINARNO
}

Received: October 2019 | Accepted: February 2020 | Published: April 2020

Please cite this paper as: Soetrioni, A.D.M., \& Winarno, S.T. (2020). An Integrated Study of Coffee and Cacao Plantation Management in Supporting Tourism-Based Agribusiness in East Java, Indonesia, Holistica Journal of Business and Public Administration, vol. 11, iss. 1, pp. 59-68

\begin{abstract}
This research aims to: (1) understand the factors which become the drivers and inhibitors of the implementation of integrated management model of coffee and cocoa plantation, and (2) determine the strategy of integrated management model of coffee and cocoa plantation. The research location is determined using purposive method. The location of the research object is located in Jember Regency, Lumajang, and Malang. The research design is using descriptive and analytical survey method, while the sampling is done using Snowball Sampling method. The data analysis of this research is using: (1) Descriptive Analysis; (2) Revenue Analysis; and (3) Force implementation Analysis (FFA). The research result shows that: (a) The driving factors of the implementation of integrated management model of coffee and cocoa plantation are the variety of agricultural crops (plantation products, agricultural products, and livestock), while the inhibiting factors are weak networks among government institutions and stakeholders; and (b) The strategy of the implementation of management model are: (i) the role and participation of the community as managers; (ii) contribution from government and stakeholders; (iii) specific integrated plantation management; (iv) provision of facilities; (v) clarity of the implication of the model on local communities, tourists, and government. The implementation of the principles model can be operationalized, after it is agreed upon by stakeholders and if the models are 'community-based'.

Keywords: plantation management; tourism based agribusiness; stakeholders
\end{abstract}

\section{Introduction}

In East Java, coffee and cocoa commodities have great prospect in the future, because these commodities have agro-ecosystems that are compatible with the region. These

\footnotetext{
${ }^{1}$ Lecturers in Agribusiness Study Program, Faculty of Agriculture, Universitas Jember, Jember, Indonesia

2 Lecturer in Agribusiness Study Program, Faculty of Agriculture, Universitas Pembangunan Nasional "Veteran" Jawa Timur, Indonesia, sricondrowinarnoupnjatim@gmail.com

* Corresponding author
} 
commodities also have economic and ecology value, and have a role of community empowerment along the southern crossroad. The facts in the field show that the community-based cacao cultivation is relatively smaller in number compared to coffee commodities. However, many coffee plants are considered old, so that the productivity is low, around $0.543 \mathrm{kw} / \mathrm{hectare}$, and based on research, the southern lane area for cocoa commodities is unable to compete with sugarcane.

As a result, from year to year, there is a decrease in the cultivated area. Referring to the master plan of regional development for southern East Java, the region is supposed to be the center for cocoa and coffee plantation that is expected to have a multiplier effect for the surrounding communities. Botezat and Benea (2012) explained that the tourism sector is very important in the national economy, since this activity generates income, plays a role as a catalyst for other branches, becomes element to attract investment, and changes local community to be better. Wijaya and Furqan (2018) stated that tourism sector is one of the largest economic contributors in urban and regional development. Chin, et al. (2018) added that given the economic importance of winter tourism industry, people must consider climate change and potential adaptation strategies in the future planning in their decision making. Habibi, et al. (2018) found that the tourism has a positive impact toward economic growth. In Iran, it appears that tourism as a whole supports general economic growth. Therefore, strategic planning is required in its development, specifically the one related to the development of tourism-based agribusiness system. The development of commodity-based agro-tourism areas for coffee and cocoa plantation is meant to be the initial activity to spur the development of tourism economy in an area. Gradually, the development of agro-tourism activities is expected to be followed by the emergence and development of related economic activities, both horizontally and vertically, as well as the procurement of tourism services in its surrounding, so that it can grow the dynamics of the economic community.

The purpose is this research is to analyze: the factors which become the drivers and inhibitors of the implementation of integrated management model of coffee and cocoa plantation, and (2) determine the strategy of integrated management model of coffee and cocoa plantation.

\section{Literature Review}

Cibinskiene and Snieskiene (2015) stated that in order to calculate the competitiveness index of city tourism, the quantitative measure of the tourism competitiveness of the cities analysed must be chosen. It is the development of local economy, culture, and quality of life of alternative forms of tourism in Greece (Agaliotou, 2015). In order to create contact with foreign markets, tourism must enter the international market (Mussoa \& Francionia, 2015). According to Dai et al. (2019), tourism can be used to invite tourists by packing local identity into a product. Hidayati et al. (2016) also stated that tourism development can be realized by combining religious and nature-based tourism. 
HOLISTICA Vol 11, Issue 1, 2020, pp. 59-68

Petroman, et al. (2016) mentioned several steps that must be followed to develop new tourism product that meet the requirements for consumers. It turns out that Islamic countries also take part in the trend of economic growth and the process of extraordinary structural change from the world tourism sector (Dincer, et al., 2015). In other aspect of tourism, Yachin (2018) stated that learning from customers gives companies the opportunity for tourism sector companies to be personally involved with their customers. Demarcoa (2016) stated that tourism service is basically promotional experiences. However, the competitive advantage of tourist destination is basically comes from ability to fulfil those needs. Nowadays, tourism world has been developing lately due to the impact of the internet (Folques, 2015).

One of the developments is thermal tourism, whichseen as a new opportunity for tourism (Emira \& Arslanturk, 2015). Aarstad, et al. (2018) claimed that by pursuing certain strategies, companies can form a network structure. The potential offered in a tourism location indicates the value of tourism welfare (Pyke, et al., 2016). It is explained by Estrada-Carmona, et al. (2014) that the key for multi-function landscapes include agricultural production, ecosystem, conservation, human livelihoods, institutional planning, and coordination. The research results from Zaridis, et al. (2015) shows that multidimensional market has some specific impacts on the agribusiness market in Greece. In order to achieve the goal of tourism development, Rosdiana, et al. (2014) suggested opening more employment opportunities, increase community profits to improve their welfare, and improve agricultural sustainability. It appears that, food products that require little technological equipment for processing and not based on stringent food safety standards, such as honey; seem to be sufficient to exploit the potential of marketing in connection with rural tourism (Huller, et al., 2017).

The research result conducted by Pitchayadejanant and Nakpathom (2018) concluded that in some agricultural tourism location, the recommended activities with the highest score from visitors are reaping and tasting the fruit. It is found that having large tourism potentialdevelopment plan provides a place for the tourism itself (Abubakirova et al., 2016). For the promotion aspect of tourism, Bahcelerli and Sucuoglu (2015) found that students who have work experience have a negative attitude toward promotion compared to students who have no experience.

In short, government needs to shape the process of globalization (Goryakin, et al., 2015). The process of globalization itself can help spreading the information about tourism location and attract consumers. Ho, et al. (2018), explained thatmarket orientation and resources of value chain actors are the antecedents to position excellence. Trade is beneficial in many countries, including those that involved primarily in the value chain as suppliers (Hoekman \& Shepherd, 2015).

\subsection{Research Method}

The research location is determined using purposive method. The location of the research that is chosen is in Jember Regency, Lumajang, and Malang. Descriptive and analytical survey method are used as research design. The sampling technique is conducted using 
Snowball Sampling method (Soetriono \& Hanafie, 2007) and Sugiono (2013), which is a technique of determining a sample that is initially small in number, then enlarges. In determining the first sample, one or two people were chosen, but since the information was not complete enough, the researcher looked for someone else who seems to know better and able to complete the data provided by the previous person. In addition, this study also uses expert speakers or experts who can be used as examples and must have certain conditions. These conditions, among others, include having the ability and able to understand the problems related to the development of educational-based agribusiness tourism in the coffee and cocoa center region.

\subsection{Data Analysis Technique}

First, the data analysis technique is using triangulation descriptive analysis as a support for descriptive analysis (Bakri, 2002). Triangulation is a technique of increasing the validity of qualitative data by collecting data and drawing conclusions from various different perspectives. The triangulation technique consists of 4 (four) types, namely: data triangulation, researcher triangulation, methodological triangulation, and theoretical triangulation.

Second, the data analysis technique is using the determination of development strategy based on the driving and inhibiting factors with expert interviews, and then it is analyzed using Force Field Analysis (FFA) method or strength field analysis. This analysis is useful to determine the direction of change of an activity, which in this case is the development of educational-based tourism in the coffee and cocoa center region in South Lintar Line in East Java (Sianipar \& Entang, 2003).

The factors that become the drivers and inhibitors are sourced from internal and external factors. The driving factor is a combination of strengths and opportunities, while the inhibiting factor is the combination of weaknesses and threats. In this FFA practice, it is only divided into two factors, which are driving and inhibiting factors. The first reason is because it makes it easier for researchers to determine and include the existing factors in the field into driving and inhibiting factors. The second reason is the determination of the factors is based on theory and development in the field on a macro basis, meaning that it is not included in a particular institution/group.

The assessment of each identified factor determines the success factor of the goal. The value determination is done by analyzing the driving and inhibiting factors for the development of educational-based tourism village. There are several aspects that need to be considered in assessing each factor, namely:

1. The urgency of factors towards the goal, consists of Urgency Value (NU) and Weight Factor (BF),

2. The support of factors toward the goal, consists of Support Value (ND) and Support Weight Value (NBD), and

3. Linkages between factors toward the goal, consists of Linkage Value (NK), Linkage Average Value (NRK), and Linkage Weight Value (NBK). 
HOLISTICA Vol 11, Issue 1, 2020, pp. 59-68

The assessment of each driving and inhibiting factor can be done quantitatively, but without being supported by accurate data, it will be very difficult to do so. In general, the assessment can be done using quantified qualitative values. Determining the aspect of Urgency Value (NU) from each driving and inhibiting factor can be done using comparative technique. Comparation technique is a technique that compares between one factor and another by using the question, "Which is more urgent between factor D1 and D2 in supporting the achievement of goals?" For assessing the urgency value of this factor, a comparative format is designed as presented in Table 1.

Table 1 Level of Urgency between Factors

\begin{tabular}{|c|c|c|c|c|c|c|}
\hline \multirow[b]{2}{*}{ No. } & \multirow[b]{2}{*}{ Factors } & \multicolumn{4}{|c|}{ Comparation Level of Urgency Factor } & \multirow{2}{*}{$\begin{array}{c}\text { Urgency } \\
\text { Value } \\
\text { (NU) }\end{array}$} \\
\hline & & D1 & D2 & D3 & D4 & \\
\hline 1. & D1 & $X$ & & & & \\
\hline 2. & D2 & & $X$ & & & \\
\hline 3. & D3 & & & $x$ & & \\
\hline 4. & D4 & & & & $x$ & \\
\hline
\end{tabular}

Source: Author proposal

The value determination for aspects of support and linkages factors is done using Likert scale. Considering the driving and inhibiting factors identified directly from the expert, it can be assessed quantitatively using a value scale from 1 to 5 . The provisions of the value are:

- Number 5: Very High (Support/Linkage Value)

- Number 4: High(Support/Linkage Value)

- Number 3: Sufficient/Average (Support/Linkage Value)

- Number 2: Low(Support/Linkage Value)

- Number 1: Very Low(Support/Linkage Value)

Based on this value, the urgency value from each factor that is compared is calculated. The urgency value of each factor is then weighted and then included in the evaluation table. The final value of the evaluation table is the key success factor (FKK). The key success factor of each driving and inhibiting factors are then changed into graphic. The magnitude of the key success factor value is expressed in the form of lines in the opposite direction between driving and inhibiting factors. The graphic scale shows how much the value of each factor to drive or inhibit the development of educational-based tourism village.

\section{Results and Discussion}

There are several criteria of tourism object that can support the development of agrotourism. Jember Regency has a potential and tourism advantages of ecotourism in the development of coffee commodities, which located in Sidomulyo Village, Silo Subdistrict. 
HOLISTICA Vol 11, Issue 1, 2020, pp. 59-68

Besides, in the same location there are also coffee processing units with a wet-processing method that can produce coffee with good quality. Lumajang Regency has an advantage for coffee agro-tourism in Pronojiwo Village that can be developed with educationalbased agribusiness tourism concept. The coffee tourism can be supported by other agricultural commodities, such as salak, clove, and livestock.

In Malang Regency, the concept of agro-tourism that can be developed is located in Dampit Subdistrict with the superior commodity of coffee plants, which is supported by bio-urine fermentation from livestock waste. The entire concept in each of these regions still requires handling both in terms of human resources, natural resources, facilities, and infrastructure.

Driving and Inhibiting Factors of the Implementation of Integrated Model of Cocoa and Coffee Plantation Management to Support Tourism-Based Agribusiness in East Java.

Table 2 Evaluation of Driving Factors of the Implementation of Integrated Model of Coffee and Cocoa Plantation Management to Support Tourism-Based Agribusiness in East Java

\begin{tabular}{|c|c|c|c|c|c|c|c|c|}
\hline No & Driving Factor & BF & ND & NRK & NBD & NBK & TNB & FKK \\
\hline D1 & $\begin{array}{l}\text { Variety of agricultural crops } \\
\text { (plantation products, agricultural } \\
\text { products, and livestock). }\end{array}$ & 0,17 & 4 & 3,00 & 0,67 & 0,76 & 1,62 & $1^{*}$ \\
\hline D2 & $\begin{array}{l}\text { Experienced in farming and raising } \\
\text { livestock activities. }\end{array}$ & 0,08 & 2 & 3,11 & 0,17 & 0,22 & 0,37 & \\
\hline D3 & $\begin{array}{l}\text { The uniqueness of natural and } \\
\text { environmental resources. }\end{array}$ & 0,25 & 3 & 3,11 & 0,75 & 0,73 & 1,59 & \\
\hline D4 & $\begin{array}{l}\text { Support for infrastructure and } \\
\text { information media. }\end{array}$ & 0,17 & 1 & 2,00 & 0,17 & 0,29 & 0,43 & \\
\hline D5 & $\begin{array}{l}\text { Local government and } \\
\text { stakeholder support for tourism } \\
\text { development. }\end{array}$ & 0,17 & 3 & 3,33 & 0,50 & 0,48 & 0,90 & \\
\hline D6 & Regional autonomy policy & 0,17 & 3 & 3,44 & 0,50 & 0,49 & 0,92 & \\
\hline
\end{tabular}

*) is a priority (FKK); Source: Authors computation

Information:

Urgency Value (NU); Factor Weight (BF);Support Value (ND);Support Weight Value (NBD);Linkage Value (NK); Linkage Average Value (NRK); Linkage Weight Value (NBK); and Key Success Factor(FKK).

Based on Table 2, it can be seen that the Key Success Factor (FKK) of the driving factor, namely Factor D1 (Variety of agricultural crops: plantation product, agricultural products, and livestock) has an Urgency Value of 1.62, which means the location of the research has biophysical condition and is potential to be developed as an integrated management area that leads to tourism.

Table 3 Evaluation of Inhibiting Factors of the Implementation of Integrated Model of Coffee and Cocoa Plantation Management to Support Tourism-Based Agribusiness in East Java

\begin{tabular}{lllllllll}
\hline No & Inhibiting Factor & BF & ND & NRK & NBD & NBK & TNB & FKK \\
\hline H1 & $\begin{array}{l}\text { Uncertainty in cultivation results } \\
\text { as a result of climate anomalies }\end{array}$ & 0,29 & 4 & 2,56 & 1,14 & 0,73 & 1,87 &
\end{tabular}


HOLISTICA Vol 11, Issue 1, 2020, pp. 59-68

H2 Barriers to the implementation of

$\begin{array}{lllllll}\text { the agribusiness system } & 0,14 & 4 & 3,00 & 0,57 & 0,43 & 1,00\end{array}$

H3 Weak networks between government agencies and stakeholders

$\begin{array}{lllllll}0,29 & 5 & 3,33 & 1,43 & 0,95 & 2,38 & 1^{*}\end{array}$

H4 Low awareness and community participation in supporting agricultural-based tourism

$\begin{array}{llllll}0,29 & 2 & 3,44 & 0,57 & 0,98 & 1,56\end{array}$

*) is a priority (FKK); Source: Authors computation

Based on Table 3, it can be seen that the Key Success Factor (FKK) of the inhibiting factor of the implementation of integrated model of coffee and cocoa plantation management to support tourism-based agribusiness in East Java, namely Factor H3 (Weak networks between government agencies and stakeholder) has an Urgency Value of 2.38.

This means that the of roles and contributions of all competent stakeholders with an interest in developing an integrated coffee and management plantation management to support tourism-based agribusiness in East Java is relatively low.

Figure 1 Strength Field Map of Driving and Inhibiting Factors

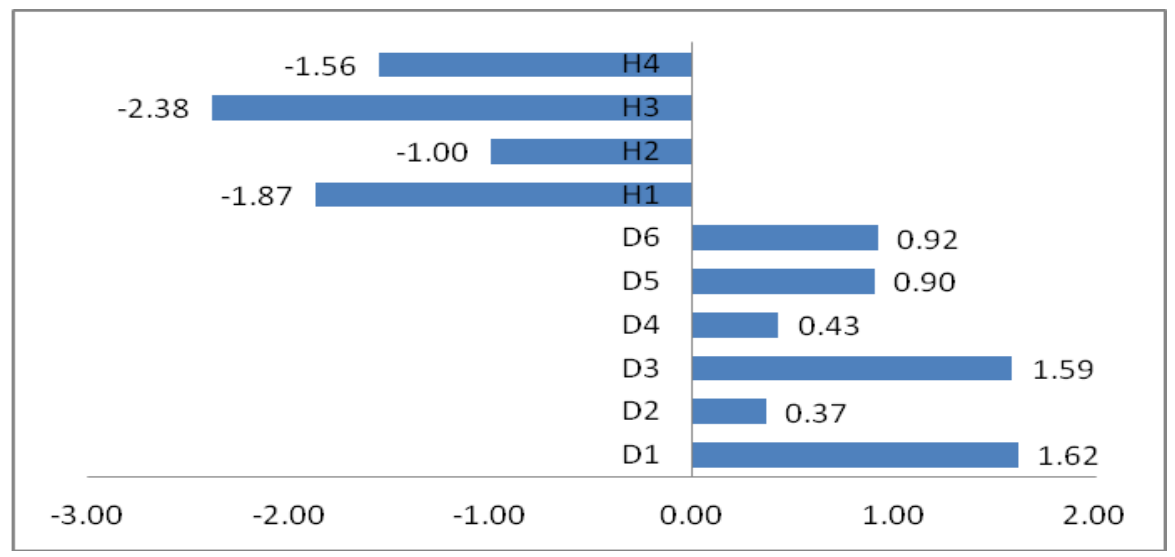

Source: Authors computation

Implementation Strategy of Integrated Model of Coffee and Cocoa Plantation Management to Support Community Welfare of the Farmers. The integrated model of cocoa and coffee plantation management packaged in the form of tourism in Jember Regency, Lumajang, and Malang is an appropriate concept and it actively helps to maintain the continued use of socio-cultural and natural environment. For this reason, a strategy to implement the model is required that involves active participation in a balanced manner between the government, private sector, and community.

The model must be elaborated into the principles of operationalization agreed upon by the stakeholders from various sector (multi-sector). It is expected that by doing this, the agreement and similarity of the viewpoints can realize the orientation of the development of integrated tourism and have a principle of "Community-Based". This principle 
HOLISTICA Vol 11, Issue 1, 2020, pp. 59-68

emphasizes direct community involvement in all activities from planning, implementation, to supervision.

The community is placed as the main factor, which has the interest of participating directly in making decisions to improve people welfare through conservation and utilization of natural resources, based on the option of owning tourism activities and infrastructure by the local community, partnerships with the private sector, and leasing land or resources both by community and cooperation with the private sector.

\section{Conclusion}

The driving/inhibiting factors of the implementation of integrated model of coffee and cocoa plantation management to support tourism-based agribusiness in East Java is variety of agricultural plants (plantation products, agricultural products, and livestock), while the inhibiting factor is the weak networks between government agencies and stakeholders.

The implementation strategies of management model include: (1) the role and participation of the community as managers; (b) the contribution of the government and stakeholders; (c) the existence of specific integrated plantation management; (d) provision of facilities; (e) the clarity of the implications of the model toward local communities, tourists, and the government. The implementation of the model must be translated into "principles of operationalization" and agreed upon by stakeholders from various sectors (multi-sector), and maintain the principles of "Community-Based".

\section{References}

Aarstad. J. H., Ness, S., Haugland, A., \& Kvitastein, O.A. (2018). Imitation strategies and interfirm networks in the tourism industry: A structure-agency approach, Journal of Destination Marketing \& Management, 9:166-174.

Abubakirova. A., Syzdykova, A., Kelesbayev, D., Dandayeva, B., \& Ermankulova, B. (2016). Place of Tourism in the Economy of Kazakhstan Republi, Procedia Economics and Finance: 39: 3-6.

Agaliotou, C. (2015). Reutilization of industrial buildings and sites in Greece can act as a lever for the development of special interest/alternative tourism, Procedia Social and Behavioral Sciences, 175:291-298.

Bahcelerli. N., \& Sucuoglu, M.E. (2015). Undergraduate Tourism Students' Opinions Regarding the Work Conditions in the Tourism Industry, Procedia Economics and Finance, 26: 1130 1135.

Bakri, M. (2002). MetodologiPenelitianKualitatif, TinjauanTeoritisdanPraktis, Malang: LembagapenelitianUniversitas Islam Malang.

Botezat, E.A., \& Benea, C.B. (2012). Stimulating the Potential of Local Resources in order to achieveCompetitiveness in Romanian Tourism, Procedia Economics and Finance, 3: 1256 $-1261$. 
Chin. N., Byun, K., Hamlet, A.F., \& Cherkauer, K.A. (2018). Assessing potential winter weather response to climate change andimplications for tourism in the U.S. Great Lakes and Midwest, Journal of Hydrology: Regional Studies, 19:42-56.

Cibinskiene. A., \& Snieskiene, G. (2015). Evaluation of city tourism competitiveness, Procedia Social and Behavioral Sciences, 213: 105 -110.

Dai, T., Hein, C., \& Zhang, T. (2019). Understanding how Amsterdam City tourism marketing addresses cruise tourists' motivations regarding culture, Tourism Management Perspectives, 29: 157-165.

Demarcoa, D. (2016). Sustainable urban development perspectives in the era of tourism experience, Procedia Social and Behavioral Sciences, 223: 335-341.

Dincer, F.I., Dincer, M.Z., \& Yilmaz, S. (2015). The Economic Contribution of Turkish Tourism Entrepreneurship on the Development of Tourism Movements In Islamic Countries, Procedia Social and Behavioral Sciences, 195: 413-422.

Emira, O., \& Arslanturk, Y. (2015). Perceptions of tourism students on thermal tourism in Afyonkarahisar, Procedia Social and Behavioral Sciences, 176: 565-570.

Estrada-Carmona, N., Hart, A.K., DeClerck, F. A.J., Harvey, C. A., \& Milder, C.J. (2014). Integrated landscape management foragriculture, rural livelihoods, and ecosystem conservation: An assessment of experience from Latin America and the Caribbean, Landscape and Urban Planning, 129: 1-11.

Folques, D.G. (2015). Anglicisms in Tourism Language Corpora 2.0, Procedia Social and Behavioral Sciences, 198: 149-156.

Goryakin, Y., Lobstein, T., Philip, W., James, T., \& Suhrcke, M. (2015). The impact of economic, political and social globalization onoverweight and obesity in the 56 low and middle income countries, Social Science \& Medicine, 133: 67-76.

Habibi, F., Rahmati, M., \& Karimi, AC. (2018). Contribution of tourism to economic growth in Iran's Provinces: GDM approach, Future Business Journal, 4: 261-271.

Hidayati, R., Sudaryono, D. W., \& Prayitno, B. (2016). Tourism development of historical riverbanks in Jatinom Village, Procedia Social and Behavioral Sciences, 227: 650-655.

Hoekman, B., \& Shepherd, B. (2015). Who profits from trade facilitation initiatives? Implications for African countries, Journal of African Trade, 2: 51-70.

Ho, K.L.P., Nguyen, C.N., Adhikari, R., Miles, M.P., \& Bonney, L. (2018). Empirical paperLeveraging innovation knowledge management to create positionaladvantage in agricultural value chains, Journal of Innovation \& Knowledge.

Huller, S., Heiny, J., \& Leonheauser, E.U. (2017). Linking agricultural food production and rural tourism in the Kazbegi district e A qualitative study, Annals of Agrarian Science, 15: 4048.

Mussoa, F., \& Francionia, B. (2015). Agri-Food Clusters, Wine Tourism and Foreign Markets. The Role of Local Networks for SME's Internationalization, Procedia Economics and Finance, 27: 334 - 343.

Netshipale, A.J., Oosting, S.J., Raidimi, E.N., Mashiloane, M.L., \& de Boer, I.J.M. (2017). Land reform in South Africa: Beneficiary participation and impact on landuse in the Waterberg District, NJAS Wageningen Journal of Life Sciences, 83: 57-66.

Petroman, C., Mirea, A., Lozici, A., Constantin, E.C., Marin, D., \& Merce, I. (2016). The Rural Educational Tourism at the Farm, Procedia Economics and Finance, 39: 88-93.

Pitchayadejanant, K., \& Nakpathom, P. (2018). Data mining approach for arranging and the agrotourism activities in orchard, Kasetsart Journal of Social Sciences, 39: 407-413. 
HOLISTICA Vol 11, Issue 1, 2020, pp. 59-68

Pyke, S., Hartwell, H., Blake, A., \& Hemingway, A. (2016). Exploring well-being as a tourism product resource, Tourism Management, 55: 94-105.

Rosdiana, H., \& Inayati, M. (2014). Evaluation of Fiscal Policy on Agropolitan Development to Raise Sustainable Food Security (A Study Case in Bangli Regency, Kuningan Regency and Batu Municipality, Indonesia), Procedia Environmental Sciences, 20: 563-572.

Sianipar, J. P. G., \& danEntang, M. (2003). Teknik-teknik Analisis Manajmen (BahanDasarDiklatpim Tingkat III), Lembaga Administrasi Negara: Jakarta.

Sugiono, (2013). Metode Penelitian Kuantitatif danKualitatif dan R\&D. Bandung: CV Alfabeta Di KabupatenMagelang, Bandung: UniversitasDipenogoro.

Soetriono dan, H. (2007). Filsafat Ilmu dan Metodologi Penelitian, Andi Offset: Yogjakarta

Wijaya, N., \& Furqan, A. (2018). Coastal Tourism and Climate-Related Disasters in an Archipelago Country of Indonesia: Tourists' Perspective, Procedia Engineering, 212: 535-542.

Yachin, J.M. (2018). The 'customer journey': Learning from customers in tourism experience encounters, Tourism Management Perspectives, 28: 201-210.

Zaridis, A.D., Mousiolis, D.T, Karamanis, K., \& Rontogianni, A. (2015). The Determinants of the Market. The Case of the Greek Agribusiness Sector, Procedia Social and Behavioral Sciences, 175: 559-566. 